\title{
Muhammad Shalih As-Samarani dalam Kacamata Masyarakat Muslim Milenial
}

\author{
Aflahal Misbah \\ Mahasiswa Pascasarjana UIN Sunan Kalijaga Yogyakarta \\ aflahalmisbah@gmail.com
}

\begin{abstract}
Muhammad Salih As-Samarani was one of the Nusantara's intellectual figures of the past which was associated with the term 'Islam Nusantara'. This figure, in some of 'Islam Nusantara' literatures, is considered as one of the representative figures to explore and discover the foundation of 'Islam Nusantara'. His actions and thoughts in the 19th century in Java, which were able to connect Mecca and Pesantren and Pesantren and society, were indeed not negligible in the effort to build 'Islam Nusantara' argument. Recognition of the As-Samarani figure, in fact, is not only a field of scientific study for scholars, but also for ordinary people who are also increasingly keen to introduce AsSamarani in public. In this paper, as a preliminary study, the author tries to focus on seeing how As-Samarani is represented in public by ordinary people through YouTube. Almost all of the videos on Youtube which try to re-display As-Samarani figure appeared after the 'Islam Nusantara' become the 33rd NU Congress in Jombang. As-Samarani's figure on Youtube shows that along with the affirmation of the term 'Islam Nusantara', the As-Samarani figure is even more interesting for ordinary people, especially in media of his magical power contexts (such as turning stones into gold, meeting Imam Ghazali, his goats are able to defeat tigers), not his actions and thoughts, or more specifically perhaps his writings.
\end{abstract}

Keywords: As-Samarani, ‘Islam Nusantara`Representation, YouTube.

\section{Abstrak}

Muhammad Shalih As-Samarani merupakan salah satu figur intelektual Nusantara masa lalu yang dikaitkan dengan term 'Islam Nusantara ’. Figur ini, dalam beberapa literatur 'Islam Nusantara ', dianggap sebagai salah satu figur yang representatif untuk menggali dan menemukan fondasi 'Islam Nusantara '. Kiprah dan pemikirannya pada abad 19 di Jawa, yang mampu menghubungkan Makkah dan Pesantren serta Pesantren dan masyarakat, memang tidak bisa diabaikan dalam upaya membangun argumen 'Islam Nusantara `. Pengenalan kembali figur As-Samarani, pada kenyataannya, bukan hanya menjadi lahan studi ilmiah para sarjana, namun juga masyarakat awam yang juga semakin giat memperkenalkan As-Samarani di ruang publik. Dalam tulisan ini, sebagai kajian awal, penulis berusaha memfokuskan diri untuk melihat bagaimana As-Samarani ditampilkan 
Millatī, Journal of Islamic Studies and Humanities, Vol. 3, No. 1, Juni 2018: 29-50

di ruang publik oleh masyarakat awam melalui media Youtube. Hampir semua video di Youtube, yang berusaha menampilkan kembali figur As-Samarani, semuanya muncul pasca `Islam Nusantara ` dijadikan Muktamar NU ke-33 di Jombang. Figur As-Samarani dalam YouTube menunjukkan bahwasanya bersamaan dengan peneguhan term `Islam Nusantara , figur As-Samarani justru lebih menarik bagi masyarakat awam khususnya di media dalam konteks kekuatan magisnya (seperti mengubah batu menjadi emas, bertemu imam Ghazali, kambingnya mampu mengalahkan harimau), bukan kiprah dan pemikirannya, atau lebih spesifik mungkin karya tulisnya.

Kata kunci: As-Samarani, Representasi Islam Nusantara, YouTube.

\section{Pendahuluan}

Dua dekade terakhir, figur Muhammad Shalih As-Samarani (selanjutnya: AsSamarani) seolah hadir kembali di masyarakat sejak satu abad kepergiannya. Figur ini semakin menguat, terutama setelah digulirkannya wacana 'Islam Nusantara ’ oleh Muktamar NU ke-33 di Jombang. ${ }^{1}$ Penggalian akar keilmuan dan metode pikir khazanah klasik yang khas Indonesia sangat dibutuhkan untuk mendukung dan mempertegas term "Islam Nusantara", sebagai metode keilmuan maupun sebagai model keislaman khas Indonesia. ${ }^{2}$ Dalam konteks ini, As-Samarani

${ }^{1}$ Di lingkungan akademisi, figur As-Samarani menguat pasca Muktamar NU ke-33. Beberapa penelitian bisa dibilang cukup melimpah, meningkat tajam dari sebelumnya. Penulis menemukan setidaknya ada enam skripsi, tiga tesis, dan tujuh artikel ilmiah. Sebagian besar cenderung menaruh perhatian pada bidang tasawuf dan tafsir As-Samarani. Lihat di antaranya Luqmi Maulana Hazim, "Kitāb Al-Mursyid Al-Wajiz fi 'Ilm Al-Qur’ān Al-Aż̉z Karya Kiai Șālị̆ Dārāt As-Samārānī” (Pascasarjana UIN Sunan Kalijaga, 2015); Lilik Faiqoh, "Vernakularisasi dalam Tafsir Faid al-Rahman Karya KH. Sholeh Darat al-Samarani” (Fakultas Ushuluddin dan Pemikiran Islam UIN Sunan Kalijaga, 2017); Ahmad Nurkholis, "Karakteristik Tafsir Sufistik Faid al-Rahman fi Tarjamah Tafsir Kalam Malik al-Madyan Karya Muhammad Shaleh Ibn Umar al-Samarani" (UIN Sunan Kalijaga, 2017); Muslich Shabir, "Corak Pemikiran Tasawuf Kyai Saleh Darat Semarang: Kajian atas Kitab Minhāj Al-Atqiyā'," International Journal Ihya”Ulum al-Din 19, no. 1 (2017): 91-128.

${ }^{2}$ Beberapa sarjana sudah melakukan upaya untuk mengukuhkan 'Islam Nusantara . Tawaran pemikiran banyak ditulis dalam artikel ilmiah-pendek dengan jumlah halaman di kisaran 20-an. Ini bisa dilihat misalnya seperti; Khabibi Muhammad Luthfi, "Islam Nusantara: Relasi Islam dan Budaya Lokal," SHAHIH: Journal of Islamicate Multidisciplinary 1, no. 1 (2016): 1-12; Ngatawi Al-Zastrouw, "Mengenal Sepintas Islam Nusantara," Hayula: Indonesian Journal of Multidisciplinary Islamic Studies 1, no. 1 (2017): 1-18; Saiful Mustofa, "Meneguhkan Islam Nusantara Untuk Islam Berkemajuan: Melacak Akar Epistemologis dan Historis Islam (di) Nusantara,” Epistemé: Jurnal Pengembangan Ilmu Keislaman 10, no. 2 (2015): 405-434; Mujamil Qomar, "ISLAM NUSANTARA: Sebuah Alternatif Model Pemikiran, Pemahaman, dan Pengamalan Islam,” El-HARAKAH 17, no. 
menempati salah satu posisi sentral dalam diskursus `Islam Nusantara `. Kiprah dan pemikirannya pada abad 19 diharapkan menjadi salah satu rujukan penting, terlebih jika diposisikan sebagai 'kajian Islam pesisiran', seperti yang diharapkan oleh Munawir. ${ }^{3}$ Namun, pandangan ini perlu ditinjau ulang jika melihat kiprah As-Samarani secara lebih seksama. Sebab, kiprahnya, seperti yang ditulis Bizawie yang mirip dengan pandangan Jajat sebelumnya, terbilang sangat luas jangkauannya. Dia mampu membangun penyerasian antara Makkah dengan pesantren, kemudian pesantren dengan masyarakat. ${ }^{4}$ Langkah demikian tidak lepas dari beberapa faktor fundamental, salah satunya adalah karya beraksara Pegonnya yang memiliki kontribusi besar terhadap perkembangan Islam di Jawa. ${ }^{5}$ Buku-bukunya beraksara Pegon kini menjadi salah satu variabel dalam diskursus 'Islam Nusantara ', terutama dalam konteks pendidikan. ${ }^{6}$ Melihat kiprahnya yang demikian, tidak mengejutkan ketika As-Samarani dijadikan rujukan oleh para pendukung Islam Nusantara.

Penting dicatat, bersamaan dengan euforia atas pengukuhan 'Islam Nusantara` -bagi yang setuju atas istilah ini- disertai dengan pendalaman, pengkajian, serta penggalian sejarah Islam Indonesia, khususnya yang berkaitan dengan aktor intelektual masa lalu, secara tidak langsung masyarakat umum jika dipahami dengan seksama, juga terkena imbasnya. Dalam artian, mereka juga tidak mau kalah dengan para peneliti atau akademisi. Mereka berupaya semaksimal mungkin untuk melakukan hal yang dianggap penting untuk mendukung pengukuhan ini. Figur As-Samarani, dalam hal ini, cukup banyak menarik perhatian khalayak. Dengan gaya mereka sendiri, As-Samarani terus dihadirkan di ruang publik pasca menggemanya istilah `Islam Nusantara `?

2 (2015): 198-217; Abdul Basid, "Islam Nusantara; Sebuah Kajian Post Tradisionalisme dan Neo Modernisme,” Tafáqquh: Jurnal Penelitian Dan Kajian Keislaman 5, no. 1 (2017): 1-14.

${ }^{3}$ Munawar Aziz, "Konsep Peradaban Islam Nusantara: Kajian atas Pemikiran Syekh Ahmad Mutamakkin (1645-1740) dan KH Sahal Mahfudz (1937-2015)," Jurnal Lektur Keagamaan 13, no. 2 (2015), 457.

${ }^{4}$ Zainul Milal Bizawie, Masterpiece Islam Nusantara: Sanad dan Jejaring Ulama-Santri (Tangerang: Pustaka Kompas, 2016), 430-446; Bandingkan Jajat Burhanudin, "Islamic Knowledge, Authority and Political Power: the Ulama in Colonial Indonesia" (Universiteit Leiden, 2007), 123-144.

${ }^{5}$ Baca Saiful Umam, "Localizing Islamic Orthodoxy in Northern Coastal Java in the Late 19th and Early 20th Centuries: A Study of Pegon Islamic Texts" (University of Hawaii at Manoa, 2011).

${ }^{6}$ Abdul Munip, "Tracing the History of the Arabic-Javanese Language Translation Books in Nusantara Islamic Education,” Jurnal Pendidikan Islam 5, no. 1 (2016), 48-49.

${ }^{7}$ Banyak data yang bisa disebutkan terkait hal ini, namun dalam tulisan ini penulis hanya akan fokus pada representasi As-Samarani yang dilakukan oleh masyarakat melalui Youtube. 
Millatī, Journal of Islamic Studies and Humanities, Vol. 3, No. 1, Juni 2018: 29-50

Beranjak dari uraian singkat di atas, di sini penulis berusaha mengkaji As-Samarani melalui representasi yang dilakukan oleh masyarakat umum. Selama ini, beberapa studi terkait As-Samarani cenderung banyak menaruh perhatian di bidang pergerakan dan pemikirannya pada masa kolonial, tepatnya Akhir Abad 19. Hal ini bisa dilihat di antaranya studi yang dilakukan oleh Ghazali Munir, Basri, Saiful Umam, dan Ali Mas'ud. ${ }^{8}$ Ghazali berusaha mengungkap pemikiran kalam As-Samarani, baik dari sisi historis maupun dari sisi genealogi pemikiran. Setahun berikutnya, Basri ${ }^{9}$ melakukan studi perbandingan tiga ulama sentral pada abad 19, salah satunya As-Samarani. Kajian historisnya menempatkan AsSamarani sebagai figur yang disebutnya dengan `reformis realis `. Pandangannya ini tiga tahun kemudian di afirmasi oleh Saiful Umam dan Ali Mas `ud. Umam dengan titik tekannya pada karya beraksara Pegon menyimpulkan bahwa AsSamarani merupakan tokoh yang berhasil menumbuhkembangkan ajaran Islam ortodoks di Jawa, meskipun ajaran itu sudah muncul sejak awal islamisasi. Dalam konteks yang lebih spesifik, Ali Mas'ud -secara tidak langsung- dengan kajian tasawufnya menempatkan figur As-Samarani sebagai tokoh sufi yang berbeda dari para sufi di Indonesia sebelumnya. Dia menyebut ajaran tasawuf As-Samarani sebagai 'tasawuf sunni fundamentalis` .

Melihat beberapa studi di atas serta beberapa studi lain yang tidak bisa disebutkan semua di sini, penulis akan mencoba memfokuskan diri untuk melihat As-Samarani dari perspektif lain, yaitu pada pergerakan atau penghadiran As-Samarani di era kontemporer bersamaan dengan menggaungnya tema ‘Islam Nusantara '. Maksud penulis di sini bukan untuk melihat wujud figurnya secara langsung, sebab sudah tidak ada sejak satu abad yang lalu. Namun, di sini penulis berusaha melihat sosok As-Samarani yang dihadirkan kembali oleh masyarakat.

Sebagai studi awal, penulis baru sebatas memfokuskan diri pada salah satu media yang digunakan oleh masyarakat, Youtube. Media ini menjadi salah satu

Lebih lengkapnya pembaca bisa melihat di bagian pembahasan nanti.

${ }^{8}$ Ghazali Munir, "Pemikiran Kalam Muhammad Salih Darat As-Samarani (18201903)" (Program Pascasarjana UIN Sunan Kalijaga, 2007); Basri, "Indonesian Ulama in the Haramayn and the Transmission of Reformist Islam in Indonesia (1800-1900)" (University of Arkansas, 2008); Umam, "Localizing Islamic"; Ali Mas'ud, "Dinamika Sufisme Jawa: Studi tentang Pemikiran Tasawuf KH. Saleh Darat Semarang dalam Kitab Minhaj al-Atqiya”” (Program Pascasarjana UIN Sunan Ampel, 2011).

${ }^{9}$ Terkait studi Basri, penulis belum bisa mengakses hasil penelitiannya secara penuh karena beberapa keterbatasan, baik secara personal maupun secara institusional dan administratif. Penulis hanya bisa mengakses gambaran abstraknya melalui website perpustakaan Universitas Ankarsas. Buka https://library.uark.edu/record=b2585131 S4 
alat bantu yang signifikan bagi masyarakat untuk merepresentasikan sosok AsSamarani. Sifat praktisnya untuk menampilkan informasi, tanpa harus membaca dan cukup mendengarkan dan melihat, menjadikan media ini banyak menarik kalangan baik untuk memproduksi informasi atau sekadar mengonsumsinya. ${ }^{10}$ Perlu ditegaskan di sini bahwa, penulis tidak hanya melihat produser atau konsumen saja, penulis akan mencoba melihatnya secara komprehensif. Baik produser atau konsumen, keduanya penulis posisikan sebagai khalayak umum yang sama-sama berupaya menampilkan kembali sosok As-Samarani, meskipun hanya sebatas menampilkan dalam ruang memorinya, yaitu mengenalnya. ${ }^{11}$

Sebelum melangkah lebih jauh, penulis awali diskusi ini dengan pertanyaan: Bagaimana bentuk dan karakteristik figur As-Samarani yang direpresentasikan oleh masyarakat melalui media Youtube? Pertanyaan ini membantu penulis untuk tetap fokus pada topik yang penulis ajukan. Tulisan ini, meskipun tidak sebaik harapan pembaca, diharapkan bisa menambah khazanah studi tentang As-Samarani. Lebih dari itu, melalui kajian representasi As-Samarani ini, kita juga bisa melihat bagaimana bentuk manifestasi respons masyarakat terhadap salah satu figur intelektual masa lalu bersamaan dengan munculnya tema 'Islam Nusantara’ .

${ }^{10}$ Sifatnya yang mudah dan praktis untuk memproduksi dan mengonsumsi informasi menempatkan Youtube sebagai media yang sangat berpengaruh besar terhadap kehidupan sosial. Ini bisa dibaca lebih lanjut dalam artikel Anjana Susarla, Jeong-Ha Oh, dan Yong Tan, "Social Networks and the Diffusion of User-Generated Content: Evidence from YouTube," Information Systems Research 23, no. 1 (2012): 23-41.

${ }^{11}$ Perlu ditegaskan di sini, ada beberapa asumsi penulis terkait 'mengenal ' adalah bagian dari representasi; Pertama, sederhananya, salah satu dari proses penting dalam representasi adalah pertukaran makna di antara anggota masyarakat. Karenanya, ketika penerima pesan sudah `mengenal ', maka proses representasi di sini sudah berjalan. Kedua, ada dua sistem representasi, yaitu; konsep dan bahasa. Keduanya saling berkaitan satu sama lain dan keduanya saling mendukung dan melengkapi satu sama lain. Salah satu dari keduanya sudah tentu ada dalam setiap anggota masyarakat yang ingin berbagi makna. Namun, keduanya tidak mungkin dipisahkan secara tegas, dan juga tidak mungkin harus ada semuanya secara bersamaan dalam setiap anggota masyarakat. Oleh karenanya, ketika masyarakat baru sebatas ‘mengenal ', maka sistem representasi sudah berjalan. Ini karena dalam kondisi 'mengenal ' tersebut, masyarakat telah memakai bahasa yang berisi banyak tanda dan kode yang sudah masuk secara perlahan sejak lahir. Jadi, representasi bukan hanya berisi makna, produksi, dan praktek produksi makna, melainkan lebih kompleks lagi variabelnya. Bandingkan Stuart Hall, "The Work of Representation,” dalam Representation: Cultural Representations and Signifying Practices (SAGE, 1997), 15-30. 
Millatī, Journal of Islamic Studies and Humanities, Vol. 3, No. 1, Juni 2018: 29-50

\section{Islam Nusantara, As-Samarani, dan New Media}

Muktamar NU ke-33 di Jombang yang mengangkat tema Islam Nusantara membuat beberapa kalangan harus mempekerjakan mesin berpikirnya, satu sisi berusaha menolak semaksimal mungkin, di satu sisi berada dalam posisi kebalikannya. Bagi yang menolak, rentetan argumen logis dan sistematis terus dibangun untuk menggugurkan term itu yang dinilai tidak tepat dan semakin menambah persoalan. Sebaliknya, para pendukung term Islam Nusantara sudah siap dengan berbagai argumen yang tersusun secara rapi untuk menjawab kritikan dan penolakan dari kelompok-kelompok yang tidak setuju atas istilah itu. ${ }^{12} \mathrm{Jika}$ dilihat seksama, keduanya sama-sama kuat dan sama-sama berambisi.

Terlepas dari adanya perdebatan pro dan kontra, satu hal penting yang patut dicatat adalah munculnya upaya perkenalan kembali masyarakat terhadap para tokoh Islam Indonesia masa lalu. Figur-figur sentral Islam masa lalu kembali dihadirkan dan diperkenalkan kembali kepada masyarakat, terutama oleh kelompok pendukung gagasan Islam Nusantara. Ini mengingat gagasan Islam Nusantara yang diklaim sebagai Islam yang ramah, toleran, damai, inklusif, tidak lain merupakan produk berantai dari para ulama dalam setiap periode dan generasinya. Mereka, dalam sejarahnya, banyak menggunakan strategi kebudayaan atau biasa dikenal dengan akulturasi budaya. Pelopor dari strategi ini biasa diasosiasikan oleh banyak kalangan kepada Walisongo sebagai generasi ulama yang sukses menyebarkan dan membumikan Islam di bumi Nusantara dalam waktu yang cukup singkat.

Islam Nusantara tidak lain hanyalah sebuah nama, label, atau merek, sementara dalam prakteknya sudah berlangsung sejak Islam masuk ke Indonesia, ${ }^{13}$ Asia Tenggara dalam konteks lebih luasnya. Tidak ada yang beda dengan ajaran Islam yang dibawa oleh Nabi Saw, perbedaan hanya terletak pada cara penerapan dan penyebaran ajaran agama, mengingat konteks Arab dan

${ }^{12}$ Pro-kontra term Islam Nusantara sudah cukup banyak direkam oleh para sarjana Asing seperti Gwenael Njoto-Feillard, Ripples from the Middle East: The Ideological Battle for the Identity of Islam in Indonesia (Singapore: ISEAS Yusof Ishak Institute, 2015); Alexander Raymond Arifianto, "Islam Nusantara: NU's Bid to Promote 'Moderate Indonesian Islam," RSIS Commentary, S. Rajaratnam School of International Studies, Nanyang Technological University, 2016; Alexander Raymond Arifianto, "Islam Nusantara \& Its Critics: The Rise of NU's Young Clerics," RSIS Commentary, S. Rajaratnam School of International Studies, Nanyang Technological University, 2017.

${ }^{13}$ Lukman Hakim Saifuddin, "Islam Nusantara dan Pembentukan Karakter Bangsa," dalam Masterpiece Islam Nusantara: Sanad dan Jejaring Ulama-Santri (1830-1945) (Tangerang: Pustaka Kompas, 2016), xix-xx. 
Indonesia berbeda. Barangkali, jika Nabi Saw masih hidup saat ini, mungkin melihat apa yang dilakukan oleh para ulama Indonesia dari satu generasi ke generasi adalah tindakan yang tepat, sebab tujuan utama dari agama Islam adalah sebagai rahmat bagi semuanya, tanpa terkecuali. Dan, hal ini mampu terwujud di bumi Nusantara.

Kejeniusan dan kearifan para ulama dari satu abad ke abad berikutnya dalam mendiseminasikan ajaran Islam, jelas sekali sangat kuat dijadikan pijakan dasar untuk memperkokoh gagasan Islam Nusantara itu sendiri. Ini bisa dilihat pada buku Gerakana Kultural Islam Nusantara (2015), yang ditulis oleh Tim JNM (Jamaah Nahdhiyin Mataram) bekerja sama dengan Panitia Muktamar NU ke 33..$^{14}$ Bagian 4 buku itu (temanya; Para Guru dalam Pembentukan Jaringan Islam Nusantara Abad ke-17, Abad ke-18, Abad ke-19) jelas mengangkat dan memperkenalkan figur-figur sentral Islam Nusantara yang membentuk sebuah hubungan secara kontinu. Hal ini kemudian diulangi lagi pada bagian ke 6 dengan topik "Warisan Islam Nusantara, Tentang Manuskrip dan Aksara PegonMakna Gandul". Meski topik yang diangkat tentang khazanah manuskrip dan aksara pegon, namun para penulis nampaknya lebih memilih untuk menyajikan para kreator manuskrip itu sendiri. Lebih-lebih penjelasan itu nampak dilakukan secara kronologis, dalam arti dari tokoh satu beralih tokoh berikutnya dilakukan berurutan sesuai masa hidup dan perjuangannya. Beberapa tokoh yang disebutkan dalam bagian 6 antara lain; Hamzah Fanshuri, Syamsudin Sumatrani (w. 1630 M), Nuruddin ar-Raniri (w. 1658 M), Abd. Rauf as-Sinkili (w. 1693 M), M. Yusuf al-Maqassari (w. 1699 M), Ahmad Mutamakkin (w. 1740 M), Tuang Rammpang (w. 1723 M), Abd. As-Samad al-Palimbani (w. 1789 M), Arsyad alBanjari (w. 1812 M), Abdullah al-Bantani, Nafis al-Banjari, Habib bin Arifudin, Ahmad Rifai Kalisalak, Nawawi al-Bantani (w. 1897 M), Khalil Bangkalan (w. 1925 M), Saleh Darat (w. 1903 M), Mahfud at-Tirmisi (w. 1919 M), A. Khatib Minangkabau (w. 1916 M), Hasyim Asy`arie (w. 1947 M), KH.R. Asnawi Kudus (w. 1959 M), Ihsan Jampes (w. 1952 M), Abu al-Fadhal Senori, Ahmad Sanoesi (w. 1950 M), Paku Buwono IV, Ky. T. Padmanagara, Amangkurat II/Paku Buwono V, Mangkunegara IV dan Ronggowarsito.

Figur Shalih Darat atau As-Samarani tidak bisa diabaikan begitu saja dari diskursus Islam Nusantara, terutama posisinya yang semakin menguat pasca digelarnya Muktamar NU ke-33. Dalam buku di atas nampak jelas bagaimana

${ }^{14}$ Tim Penulis JNM, Gerakan Kultural Islam Nusantara (Yogyakarta: Jamaah Nahdliyin Mataram (JNM) \& Panitia Muktamar NU ke-33, 2015). 
Millatī, Journal of Islamic Studies and Humanities, Vol. 3, No. 1, Juni 2018: 29-50

menggambarkan posisi dan kontribusinya -meski dipaparkan cukup singkatterhadap perkembangan Islam di Indonesia Abad 19. Relasinya dengan Kartini, karya-karyanya beraksara Pegon, serta murid-muridnya yang menjadi para ulama besar Abad 20, menjadi titik tekan buku itu ketika mendeskripsikan biografi As-Samarani.

Buku lain yang juga concern dalam memperkenalkan figur-figur sentral Islam Nusantara adalah karya Milal Bizawie (2016), Masterpiece Islam Nusantara: Sanad dan Jejaring Ulama-Santri. ${ }^{15}$ Buku ini terbilang sangat kaya akan data para figur Islam Nusantara, namun juga sangat rumit untuk dibaca, karena hampir setiap paragraf berisi banyak tokoh yang saling berjejaring satu sama lain membentuk sebuah jaringan. Butuh konsentrasi dan kehatian-hatian dalam membacanya agar tidak salah menangkap maksud dari Milal. Dalam buku ini, figur As-Samarani disebut Milal sebagai salah satu jejaring utama yang menjadi titik pusat simpul di Nusantara. Artinya, tidak mungkin mengabaikan sosok ini ketika menggemakan gagasan Islam Nusantara.

Figur As-Samarani dan Islam Nusantara ibarat dua sisi mata uang yang tidak mungkin dipisahkan. Posisinya berada di penghujung Abad 19 yang memiliki andil sangat besar kepada masyarakat. Dalam bahasa Jajat Burhanudin, As-Samarani merupakan salah satu tokoh yang membentuk komunitas santri, menghubungkan Mekkah dengan pesantren, kemudian pesantren dengan masyarakat. ${ }^{16}$ Bukti konkret dari gerakan ini bisa dilihat pada karya Pegonnya yang mampu tercetak berulang kali, jumlahnya mencapai ribuan eksemplar. Dalam studi Proudfoot, tercatat 30.800 eksemplar kitab As-Samarani tercetak, itu pun hanya sembilan dari empat belas karya As-Samarani yang berhasil dicatat oleh Proudfoot. Di samping itu, catatan Proudfoot juga tidak menyebut secara keseluruhan terbitan satu kitab yang sampai dicetak hingga sepuluh kali. Artinya, jumlah keseluruhan terbitan dari sembilan kitab tidak terdeteksi secara utuh. Proudfoot hanya mencatat apa yang terdaftar di pemerintah kolonial. ${ }^{17}$ Ini karena, menurutnya, tidak semua buku keislaman didaftarkan ke pemerintah kolonial, meskipun ada denda 25 dolar untuk buku yang tidak di daftarkan. ${ }^{18}$

${ }^{15}$ Bizawie, Masterpiece Islam Nusantara: Sanad dan Jejaring Ulama-Santri.

${ }^{16}$ Burhanudin, "Islamic Knowledge, Authority and Political Power.", 123-130.

${ }^{17}$ Ian Proudfoot, Early Malay printed books: A provisional account of materials published in the Singapore-Malaysia area up to 1920, noting holdings in major public collections (Academy of Malay Studies and The Library University of Malaya, 1993), 186-187, 228, 231, 284, 320, 327-329, $347,356-359$.

${ }^{18}$ Ian Proudfoot, "A formative period in Malay book publishing," Journal of the Malaysian 
Dua buku di atas hanya sedikit gambaran bagaimana As-Samarani menempati salah satu posisi sentral dalam penyebaran gagasan `Islam Nusantara ’ Masih banyak tulisan-tulisan lain yang menyematkan nama As-Samarani sebagai figur penting yang harus digali dan dikaji pemikirannya, sebagian lain sudah penulis jadikan referensi dalam tulisan ini. Jelasnya, penting dicatat bahwa bersamaan dengan pembumian 'Islam Nusantara ’yang lebih banyak dilakukan oleh para akademisi, peneliti, atau orang-orang berpendidikan tinggi, masyarakat awam juga memiliki peran unik dalam situasi ini. Meskipun posisinya, bisa dikatakan, hanya sebagai objek dari para pencetus 'Islam Nusantara ', masyarakat awam juga memiliki ruang tersendiri untuk merespons dan memberikan reaksi sesuai dengan kedudukan mereka, apakah sebagai penerima yang mendukung atau yang menolak.

Anggapan ini barangkali masih bisa diragukan ketika belum ada media komunikasi yang semakin berkembang lebih canggih seperti sekarang ini. Melihat konteks saat ini, peran media baru, yang semakin bertambah banyak dan bervariasi, merupakan faktor penting atas kebebasan masyarakat untuk ikut campur terhadap setiap persoalan yang sedang ramai dibicarakan. 'Media baru ' mampu membentuk ruang publik baru di masyarakat, bahkan mampu membentuk masyarakat atau komunitas kecil di kalangan audiensi sendiri. ${ }^{19}$ Media ini juga sering digunakan oleh individu atau kelompok tertentu di seluruh dunia untuk mengenalkan dan membentuk identitas mereka di ruang publik, seperti suku Kurdi dan organisasi keagamaan Alevi di Turki. ${ }^{20}$

Melalui new media, figur As-Samarani semakin menarik untuk dikaji secara mendalam dalam masyarakat Islam kontemporer, karena ditampilkan dalam banyak bentuk yang bervariasi bersamaan dengan pengukuhan `Islam Nusantara `. Bukan hanya kalangan terdidik yang berupaya menampilkannya melalui kajian sistematis, rasional, disertai dengan bukti-bukti historis melalui arsip-arsip, namun juga khalayak luas yang tak mau kalah berupaya menampilkan kembali figur As-Samarani.

Branch of the Royal Asiatic Society 59, no. 2 (251 (1986), 102-103.

${ }_{19}$ Lebih lengkapnya baca Dale F. Eickelman dan Jon W. Anderson, "Redefining Muslim Publics," dalam New media in the Muslim World: The Emerging Public Sphere, 2 ed. (Indiana University Press, 2003), 1-18.

${ }^{20}$ M. Hakan Yavuz, "Media Identities for Alevis and Kurds in Turkey," dalam New Media in the Muslim World: The Emerging Public Sphere, 2 ed. (Indiana University Press, 2003), 180-99. 
Millatī, Journal of Islamic Studies and Humanities, Vol. 3, No. 1, Juni 2018: 29-50

\section{As-Samarani, Youtube, dan Ruang Presentasi Diri}

Sejak didirikan pada 2005-2006, ${ }^{21}$ Youtube kini menjadi salah satu media komunikasi yang banyak dirujuk oleh banyak kalangan. Cara menyajikan informasi yang cukup mudah, praktis, gratis, dengan cara cukup unggah video, merupakan salah satu faktor yang menjadikan media ini banyak diminati. Pada sisi lain, para audiensi juga tidak perlu membaca (seandainya memiliki hambatan seperti malas, keterbatasan fisik, atau lainnya), cukup melihat dan mendengar (itu pun apabila tidak memiliki gangguan atau kelemahan fisik). ${ }^{22}$ Karenanya, tidak mengejutkan ketika media ini menembus masyarakat Indonesia, Youtube menjadi salah satu media besar yang paling digemari. ${ }^{23}$ Beragam bentuk video yang terus di unggah oleh berbagai Youtuber selalu saja menampilkan konten yang tidak sama, wacana yang berkembang di masyarakat terkadang juga mendapat respons melalui bentuk video, baik berdurasi pendek maupun panjang. Hal ini bisa dilihat, misalnya, ketika diskursus ‘ Islam Nusantara ’ menguat, masyarakat juga tidak mau kalah, baik yang setuju atau tidak, untuk ikut serta memberikan suara melalui sebuah video di Youtube. ${ }^{24}$

Dalam konteks `Islam Nusantara`, respons khalayak bukan sebatas pada nama atau istilah itu sendiri, melainkan sampai pada apa saja yang diangkat dalam diskursus tersebut, seperti figur-figur klasik masa lalu. Dalam hal ini, As-Samarani merupakan salah satu figur yang mendapat tempat di pikiran khalayak. Kendati tidak ada pengaitan langsung melalui penyebutan istilah

${ }^{21}$ Pada tahun 2005, Youtube merupakan media independen yang didirikan oleh tiga mantan karyawan PayPal: Chad Hurley, Steve Chen, dan Jawed Karim, yang berawal dari investasi senilai \$11,5 juta dari Sequoia Capital antara November 2005 dan April 2006. Kemudian pada November 2006, Youtube resmi dibeli oleh Google dengan harga US\$1,65 Miliar, dan beroperasi sebagai anak perusahaan Google. Lihat "YouTube," Wikipedia bahasa Indonesia, ensiklopedia bebas, 6 Desember 2017, https://id.wikipedia.org/w/index.php?title=YouTube\&oldid=13420591.

${ }^{22}$ Kemudahan akses ini mendorong masyarakat untuk menampilkan sesuatu yang beragam, dari mulai berbau religius seperti Khotbah Jum'ah, [studi mengenai ini sudah dilakukan oleh Charles Hirschkind, "Experiments in devotion online: the YouTube khutba," International Journal of Middle East Studies 44, no. 1 (2012): 5-21], hingga yang berbau propaganda politik [lihat misalnya studi dari Jytte Klausen dkk., "The YouTube Jihadists: A social network analysis of Al-Muhajiroun's propaganda campaign," Perspectives on Terrorism 6, no. 1 (2012): 36-53]

${ }^{23}$ Kompas Cyber Media, "Indonesia, Penonton YouTube Terbesar se-Asia Pasifik," KOMPAS.com, diakses 26 Maret 2018, https://tekno.kompas.com/read/2015/10/20/17315317/ Indonesia.Penonton.YouTube.Terbesar.se-Asia.Pasifik.

${ }^{24}$ Pembaca bisa membuktikan sendiri dengan segera membuka handphone masing-masing dan dibuka aplikasi Youtubenya, kemudian ketik kata kunci "Islam Nusantara", selanjutnya akan muncul banyak video terkait hal ini. 
'Islam Nusantara ' dalam video As-Samarani, namun bisa dikatakan memiliki hubungan yang signifikan antara dua hal itu. Ini karena 99,99 \% dari seluruh video tentang figur tersebut, semuanya muncul pasca menguatnya diskursus 'Islam Nusantara` ${ }^{25}$

Melalui Youtube, figur As-Samarani semakin terekspos oleh khalayak sebagai tokoh yang populer. Menariknya, kepopulerannya di Youtube tidak seperti yang ditulis di beberapa literatur pada umumnya. Relasinya dengan Kartini, karya tulisnya, murid-muridnya yang menjadi ulama besar, beberapa hal ini justru tidak terlalu menonjol di Youtube. Kekuatan magis A-Samarani justru lebih menarik perhatian masyarakat; baik dari sisi penyajian sosoknya maupun dari sisi jumlah penonton. Berikut penulis akan coba uraikan beberapa poin penting dari seluruh video yang ada di Youtube yang merepresentasikan As-Samarani.

\section{Sketsa Biografi As-Samarani}

Dalam konteks riwayat hidup, narasi biografi yang disajikan di Youtube hampir tidak memiliki perbedaan signifikan dengan beberapa literatur yang sudah ada. Nama lengkapnya adalah Muhammad Shalih bin Umar as-Samarani atau Kiai Shalih Darat lahir di Jepara 1820 M/1235 H, tepatnya sebelum perang Diponegoro (1825-1830) dimulai. As-Samarani hidup sezaman dengan Syekh Nawawi al-Bantani dan Kiai Khalil Bangkalan. Ayahnya, Kiai Umar, merupakan ulama sekaligus pejuang dalam perang Diponegoro. As-Samarani kecil tumbuh di lingkungan santri dan para pejuang perang Jawa. Pendidikan pertamanya diperoleh langsung dari ayahnya, kemudian dia belajar kepada beberapa ulama di Jawa seperti, Kiai Mụ̣ammad Syahỉd (Pati), Kiai Raden Haji Muḥammad Ș ālị̆ ibn Asnāwi (Kudus), Kiai Iş̣aq (Semarang), Kiai Abu 'Abdillah Muḅammad al-Hādi ibn Bā'uni (Semarang), Kiai Darda' (Semarang). ${ }^{26}$

Pada tahun \pm 1835 M As-Samarani di ajak ke Makkah oleh ayahnya dan singgah beberapa saat di Singapura. Dalam singgahnya, As-Samarani sempat mengajar di sana hingga memiliki beberapa murid. Bahkan di Singapura juga

${ }^{25}$ Lihat daftar video di lampiran.

${ }^{26}$ Lihat PAW CHANNEL, Siapa Itu, Mbah Soleh Darat ?, t.t., https://www.youtube.com/ watch?v=lAkQOqJGsMA. Bandingkan dengan Abu Malikus Salih Dzahir, Sejarah dan Perjuangan Kyai Sholeh Darat Semarang, ed. oleh M. Ichwan (Semarang: Panitia Haul Kyai Sholeh Darat Semarang, 2012)., 5-6. Lihat pula otobiografinya dalam Mụ̣ammad Ṣālị̣ bin 'Umar as-Samārānī, al-Mursyid al-Wajizz fi 'ilm al-Quran al-Aż̈z (Bombay: al-Matba'ah al-Karimï, 1318), 118-119. 
Millatī, Journal of Islamic Studies and Humanities, Vol. 3, No. 1, Juni 2018: 29-50

terdapat kampung bernama 'Kampung Kiai Shalih `. ${ }^{27}$ Selama di Makkah, AsSamarani belajar kepada beberapa ulama prominen seperti: Syaikh Muḅammad al-Muqri al-MiṢri al-Makki, Syaikh Mụ̧ammad ibn Sulaimān Hasbullah, Syaikh Ahmad ibn Zaini Dahlān, Syaikh A’̣mad an-Nahrawi al-Misrì al-Makki, Sayyid Muḩammad Șālị̣ az-Zawāwi al-Makki, Kiai Zāhid atau Zaid, Syaikh 'Umar asySyāmi, Syaikh Y\suf as-S】nbulawi al-Misri, Syaikh Jamal, mufti Hanafi di Makkah. Dari guru-guru besarnya ini, As-Samarani belajar beberapa kitab seperti ‘Aqa id al-Barahin, Ihya 'Ulumuddin, Fath al-Wahhab, dan lain-lain. Beberapa guru -seperti Syaikh Muḩammad ibn Sulaimān Hasbullah, Syekh Ahmad Ibn Zaini Dahlan, dan Kiai Zahid- memberinya ijazah sebagai pertanda berhak dan layak untuk mengajarkan dan menyebarkan ilmunya. ${ }^{28}$

Selain belajar, As-Samarani juga sempat mengajar di Makkah. ${ }^{29}$ Pasca kembali dari Makkah, dia aktif melakukan kegiatan dakwah dengan mendirikan Pesantren Darat yang semula adalah langgar peninggalan mertuanya, Kiai Murtadho. Pesantren ini didirikan pada tahun 1880 M. Luas Pesantren Darat terbilang sangat luas sekali untuk ukuran saat itu. Bahkan untuk saat ini, menurut Agus Hamzah, luas lingkungan pondok yang bisa diselamatkan mencapai 2400 meter. $^{30}$ Dari Pesantrennya ini, beberapa muridnya menjadi pemimpin tersohor Awal Abad 20, bahkan ada yang menjadi pahlawan nasional, seperti Syekh Makhfudz at-Tirmisi ahli Hadits dikenal luas dunia internasional, Syekh Hasyim Asy'arie pendiri Nahdhatul Ulama, Syekh Ahmad Dahlan pendiri Muhammadiyah, KH. Bisyri Syansuri Pendiri Pesantren Manba `ul Ma arif Jombang, KH. Sya `ban ahli Falak Semarang, serta beberapa Kiai besar lain yang menjadi aktor penting di daerahnya masing-masing. ${ }^{31}$

Salah satu muridnya yang kerap dimunculkan dalam berbagai media, buku, surat kabar, termasuk di Youtube adalah R.A Kartini. Pertemuannya dengan R.A Kartini berawal ketika As-Samarani mengisi pengajian rutin bulanan

${ }^{27}$ Yusuf Aan, Sirah Kyai Sholeh Darat, diakses 10 Desember 2017, https://www.youtube. $\mathrm{com} /$ watch?v=YDfgtfB8n8o. Bandingkan Ghazali Munir, Warisan intelektual Islam Jawa dalam pemikiran kalam Muhammad Shalih as-Samarani (Semarang: Walisongo Press, 2008). 44.

${ }^{28}$ Lihat Yusuf Aan, Sirah Kyai Sholeh Darat., Ibid. Bandingkan dengan as-Samārānī, Al-Mursyid Al-Wajiz, 119-120.

${ }^{29}$ PAW CHANNEL, Siapa Itu, Mbah Soleh Darat?

${ }^{30}$ Muhamad Aslah, Sejarah Kyai Sholeh Darat Semarang - Sluman Slumun-Semarang TV-Editor Muhamad Aslah, diakses 10 November 2017, https://www.youtube.com/watch?v=JpDuIzWEbhc. Bandingkan Dzahir, Sejarah dan Perjuangan., 15-17.

${ }^{31}$ PAW CHANNEL, Ternyata! Pendiri NU dan Muhammadiyah Gurunya Jadi Satu, diakses 30 Desember 2017, https://www.youtube.com/watch?v=nadxx8a4qmk. 
di Pendopo Demak. R.A Kartini yang kebetulan hadir saat itu, tertarik dengan penjelasan tafsir al-Fatihah yang disampaikan oleh As-Samarani. Ketertarikan ini kemudian mendorong Kartini untuk mendesak pamannya agar mau menemaninya menemui As-Samarani. Dari sinilah, kemudian muncul pendapat bahwa tafsir Faid ar-Rahman, sebuah tafsir al-Quran berbahasa Jawa, karya Kiai Shalih sengaja dibuat untuk Kartini. ${ }^{32}$ Menariknya, relasi As-Samarani dengan Kartini tidak terlalu banyak menarik perhatian. Ini berbeda dengan representasi As-Samarani di beberapa literatur atau surat kabar online yang hampir tidak pernah meninggalkan relasi Kartini dengan As-Samarani.

Masih dengan murid As-Samarani, dalam salah satu video yang berisi ceramah KH. Yahya Mutamakkin Pengasuh Fosilatama, terdapat kisah murid As-Samarani yang menjadi Kiai kampung di sebuah kampung di Solo. Muridnya yang bernama kang Umar -dalam cerita KH. Yahya- pekerjaan setiap harinya ketika belajar di Pesantren Darat adalah mengurusi kambing-kambing AsSamarani. Dia tidak pernah belajar, bahkan menyentuh kitab pun hampir tidak pernah. Namun, ketika di suruh pulang oleh As-Samarani, dia justru menjadi ulama besar di kampungnya. Bahkan, ketika dia meminta ijazah kepada AsSamarani, justru malah dimarahi. Sebab, bagi As-Samarani yang terpenting adalah melakukan atau mengamalkan apa yang diketahui, ijazah belakangan. ${ }^{33}$

As-Samarani juga aktif berdakwah melalui pena. Menurut Agus Taufik, keturunannya, jumlah karya As-Samarani mencapai sekitar 40an kitab. Menurutnya, sebagian kitabnya sudah berhasil dikumpulkan kembali, namun sebagian lagi tidak bisa karena disimpan di perpustakaan Inggris dan Belanda. Beberapa karyanya juga ada yang disimpan di Museum Masjid Agung Jawa Tengah, seperti kitab Jauharat at-Tauhid..$^{34}$

${ }^{32}$ Lihat Nasihat Kakek, Kisah RA Kartini Jadi Santri Kyai Sholeh Darat, diakses 3 Desember 2017, https://www.youtube.com/watch?v=zpL70n0QoIQ; Ambil Baiknya?, RA Kartini Ngaji Sama Kyai Sholeh Darat, Tak Banyak Orang yang Tahu, diakses 3 Desember 2017, https://www. youtube.com/watch?v=DTAF3i7Gf_U; Mohammad Masrur, "KYAI SOLEH DARAT, TAFSIR FA'ID AL-RAHMAN DAN RA. KARTINI," At-Taqaddum: Jurnal Peningkatan Mutu Keilmuan dan Kependidikan Islam 4, no. 1 (2012): 28-45.

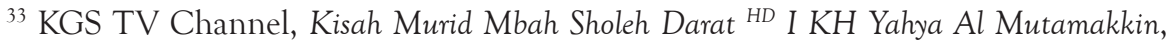
diakses 15 Desember 2017, https://www.youtube.com/watch?v=GF83szjhhgE.

34 Official NET News, Soleh Darat, Tokoh Islam Inspiratif di Tanah Jawa - IMS, diakses 10 Desember 2017, https://www.youtube.com/watch?v=GyqTRvlRBOU. Beberapa kitab yang sudah bisa diketahui antara lain; a) Faid ar-Rahman fi Tarjamah Tafsir Kalam Malik ad-Dayyan. b) Hadits al-Mi'raj. c) Manasik Kaifiyah as-Shalat al-Musafirin. d) al-Mahabbah wa al-Mawaddah fi Tarjamah Qaul al-Burdah fi al-Mạ̣abbah wa al-Madh 'alā Sayyid al-Mursalin. e) Latā' if at-Ṭahārat wa 
Millatī, Journal of Islamic Studies and Humanities, Vol. 3, No. 1, Juni 2018: 29-50

As-Samarani menghembuskan nafas terakhirnya pada hari Jum'at Legi tanggal 28 Ramadhan $1321 \mathrm{H}$ atau 18 Desember 1903 M. Makamnya selain dikenal luas masyarakat di pemakaman umum Bergota Semarang ${ }^{35}$ ternyata ada makamnya yang lain yang dipercayai ada di belakang Masjid Peninggalannya, Jl. Kakap No.212, Dadapsari, Semarang Utara, Kota Semarang. ${ }^{36}$ Banyak sekali orang yang berkunjung ke makamnya setiap hari, bahkan ada peziarah tetap setiap Minggunya, seperti Kiai Suparno, Pengasuh Pesantren Asmaul Husna, Cepogo Boyolali. Dia menjadi peziarah tetap hampir tiap Minggu dari tahun 1966 hingga sekarang. Selain sebagai peziarah tetap, dia juga aktif mempelajari karya-karya As-Samarani di pesantrennya, seperti Majmu 'at asy-Syari`at, alHikam, dan Tafsir Faidhurrahman (tafsir berbahasa Jawa Pegon). ${ }^{37}$

\section{Vis a vis As-Samarani dan Kolonial}

Bagian ini berusaha melihat vis a vis As-Samarani dan kolonial yang dipresentasikan dalam video "Mau di SOGOK Belanda - KH. Sholeh DARAT" 38 Vis a vis dalam hal ini bukan berarti perlawanan fisik As-Samarani terhadap kolonial. Keadaan vis a vis yang coba disajikan dalam narasi realitas di Youtube lebih banyak berupa perlawanan lunak disertai kekuatan magis As-Samarani. Hal ini nampak jelas dalam dua alur cerita yang tersaji dalam video tersebut. Cerita pertama menggambarkan superioritas As-Samarani ketika menundukkan Belanda. Dalam cerita ini, As-Samarani sedang berjalan kaki menuju Semarang. Ketika rombongan tentara Belanda melewatinya, mobil yang ditumpangi rombongan mati seketika. Mobil kembali hidup setelah As-Samarani diberi tumpangan oleh tentara Belanda. Dari cerita ini, nampak sekali gambaran kekuatan atau kelebihan As-Samarani, bukan sebagai figur rendahan yang bisa

Asrār aṢ-Ṣalāt fi Kaifiyyati Șalāt al-ÁAbidin wa al-'Arif Ān Șumma Yalihi Kitāb Asrār aṢ-Ṣaum Șumma Kitāb Fad̦ilah al-Muharram wa Rajab wa Sya'bān. f) Majmu'at asy-Syari'at al-Kafiyat li al-Awam. g)

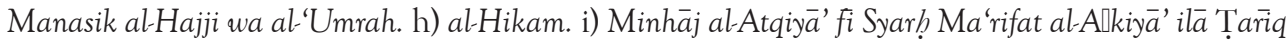

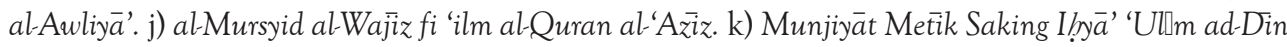
al-Ghazali. 1) Pasalatan. m) Syarh Barzanji. n) Tarjamah Sabil al-Abid 'ala Jauharat at-Tauhid. Lihat Munir, Warisan intelektual., 59-74.

${ }^{35}$ Official NET News, Soleh Darat, Tokoh Islam Inspiratif di Tanah Jawa - IMS.

${ }^{36}$ News Semarang TV, Menelusuri Jejak Peradaban Islam di Masjid Sholeh Darat Semarang, diakses 13 Desember 2017, https://www.youtube.com/watch?v=D0OnwbZk7go.

${ }^{37}$ Muhamad Aslah, Sejarah Kyai Sholeh Darat Semarang - Sluman Slumun- Semarang TV. Editor Muhamad Aslah.

38 babem ws, Mau di SOGOK Belanda | KH. Sholeh DARAT, diakses 26 Maret 2018, https://www.youtube.com/watch?v=KQoN4vXrLpg. 
diabaikan begitu saja, bahkan kolonial pun harus menghormatinya sebagai tokoh yang diperhitungkan.

Berbeda dengan cerita pertama, alur cerita kedua lebih menggambarkan As-Samarani sebagai pemimpin yang jujur dan kaya. Dalam konteks ini, dia menolak uang suap dari para serdadu Belanda yang mengajak bersekutu. Penolakan keras dari As-Samarani bukan hanya dengan sikap marah dan kesal, namun disertasi aksi magis mengubah bongkahan batu menjadi emas.

Dua peristiwa tersebut memberikan kesan adanya kekuatan magis yang melengkapi narasi resistensi As-Samarani kepada kolonial. Kaitannya dengan kekuatan magis As-Samarani akan dibahas pada bab selanjutnya. Meski perlawanannya tidak bersifat fisik dan kekerasan, namun adanya kontak langsung dengan serdadu kolonial setidaknya mampu menjawab -barangkali ada- pertanyaan-pertanyaan yang terlintas dalam benak masyarakat, apakah As-Samarani pernah berjuang melawan kolonial secara langsung? Kendati pertanyaan ini hanya asumsi penulis terhadap pikiran masyarakat, setidaknya jumlah penonton video yang cukup banyak bisa dijadikan sebagai acuan. Dalam tempo 13 bulan, dari 27 Februari 2017 hingga 26 Maret 2018, tercatat mencapai 6.183 penonton dan 59 penyuka. Memang tidak bisa dinafikan adanya pengaruh judul video yang sedikit menimbulkan rasa ingin tahu (curiosity).

\section{As-Samarani dan Imam Ghazali}

Setelah kontak dengan kolonial, di sini penulis berusaha menguraikan salah satu petikan kehidupan As-Samarani yang direpresentasikan di Youtube. Dalam video "Dikunjungi Imam Ghazali - Mbah Sholeh Darat", ${ }^{39}$ cerita yang ditampilkan mungkin adalah mitos dalam pikiran beberapa orang. Pasalnya, ada pertemuan antara As-Samarani dan Imam Ghazali. Dua tokoh yang hidup dalam rentang waktu yang sangat lama sekali, mungkin 7 abad. Sebelum pertemuan itu, Imam Ghazali lebih dahulu ditemui dan disuguhi oleh santri-santri As-Samarani. Percakapan imam Ghazali dan As-Samarani dalam bahasa Arab terbilang cukup keras meski tidak begitu jelas karena sayup-sayup suaranya terdengar oleh para santrinya. Percakapan yang berlangsung di ruang pribadi tersebut bisa dikatakan berlangsung cukup lama.

39 babem ws, Dikunjungi Imam Ghazali | Mbah Sholeh Darat, diakses 26 Maret 2018, https://www.youtube.com/watch?v=sGPC_SiiDnM. 
Millatī, Journal of Islamic Studies and Humanities, Vol. 3, No. 1, Juni 2018: 29-50

Setelah menginjak larut malam, Imam Ghazali pulang dari rumah Asamarani dengan memberi restu padanya untuk melanjutkan kitab Munjiyat yang sedang ditulis. Kitab itu merupakan petikan dari kitab Ihya Ulumuddin karya Imam Ghazali. Memang, cukup banyak karya As-Samarani yang mengutip kitab-kitab Imam Ghzali, meski pandangannya tidak sepenuhnya sama. Dalam kitab Minhaj, As-Samarani bukan hanya mengutip beberapa pandangan Imam Ghazali, dia juga memaparkan biografi singkat dari Imam Ghazali yang ditaruh dalam bab khusus. ${ }^{40}$

Hubungan intelektual As-Samarani dan Imam Ghazali memang terbilang erat sekali, terlihat dalam berbagai karya Pegon yang ditulisnya. Bahkan, bagian awal video itu diawali dengan kalimat "Mbah Sholeh Darat, beliau dijuluki Imam Ghazali-nya Jawa”. Kalimat ini menunjukkan adanya sebuah pengakuan dari masyarakat bahwa As-Samarani merupakan Imam Ghazali versinya Jawa. Mungkin tidak terlalu sulit untuk memahami relasi As-Samarani dengan Imam Ghazali dari sisi intelektual. Namun, cukup rumit dan begitu kompleks persoalannya ketika harus memahami dan menjelaskan presentasi diri AsSamarani yang bertemu dan berbicara langsung kepada Imam Ghazali. Dalam video yang di publish itu, tidak ada penonton yang men-dislike video tersebut. Meski tidak terlalu banyak menarik penonton, setidaknya dari sejak dirilis 26 Agustus 2017 hingga 26 Maret 2018, bisa dikatakan cukup mampu menarik perhatian. Ada sekitar 2749 penonton, 30 penyuka dan nihil dari tidak suka.

\section{Kekuatan `Magis`As-Samarani}

Dari sekian banyak video yang ada di Youtube, kisah kambing As-Samarani dengan harimau justru yang paling banyak menyedot perhatian masyarakat. Kisah ini bahkan tidak hanya dipresentasikan oleh satu akun satu video, tetapi lima akun dan lima video. ${ }^{41}$ Menariknya, meskipun semua kontennya sama,

${ }^{40}$ Lihat Muḥammad Șālị̣ bin 'Umar as-Samārānī, Minhāj al-Atqiyā' fi Syarḥ Ma'rifat

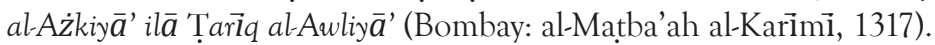

${ }^{41}$ Cerita Hari Ini, Kisah Kambing Mbah Sholeh Memakan Macan, diakses 26 Maret 2018, https://www.youtube.com/watch?v=A2kGHzUWfOU; Ferry Media Islam, Kisah Nyata Kambing Mbah Sholeh Darat Memakan Macan, diakses 26 Maret 2018, https://www.youtube. com/watch?v=u4x7KPMibcg; La Tahzan (Jangan Bersedih), Kisah Kambing Mbah Sholeh Yang Memakan Macan Milik Tamunya Yang Sombong, diakses 26 Maret 2018, https://www.youtube. com/watch?v=4I-oPo0R8t4; mei dhani, KISAH NYATA...!!! KAMBING MBAH SHOLEH MAKAN HARIMAU, diakses 26 Maret 2018, https://www.youtube.com/watch?v=PyBal_KpUtw; Roudhoh at-Tholibiin, Kisah Kambing Mbah Sholeh Darat Memakan Macan, diakses 26 Maret 
hampir tidak ada yang beda, masing-masing akun memiliki jumlah penonton dan komentar yang berbeda, bahkan ada yang tidak mendapat komentar sama sekali, seperti akun Ferry Media Islam. Hampir semua akun dipublikasikan pada tahun 2017, hanya akun Mei Dhani yang di upload pada tahun 2016 bulan Mei. Jika dilihat dengan seksama, kelima video ini bisa dikatakan paling populer dari seluruh video lainnya, sebab mampu menarik penonton sebesar 122.137 penonton hingga 26 Maret 2018, 219 penyuka dan 62 tidak suka. Mungkin jumlah ini akan terus bertambah. ${ }^{42}$

Semua kisah dalam lima video tersebut berasal dari imam Masjid Kyai Shaleh Darat, KH. Mukri Rahman. Dia mendapatkan cerita ini dari KH. Bisri Mustofa, ayah Gus Mus, saat belajar di Pesantren Leteh Rembang pada 1970-an. Kisah ini terbilang menarik, karena meskipun pemeran yang sebenarnya ingin ditonjolkan adalah harimau dan kambing. Ada campur tangan pemiliknya di situ. Penulis menyebutnya sebagai kekuatan magis As-Samarani. Magis karena secara empiris, ketika kambing dan harimau atau macan ditaruh dalam satu kandang, yang terjadi adalah penuhnya perut harimau akibat daging kambing. Kisah kambing As-Samarani memberikan nuansa lain, kambing justru mampu membunuh harimau ketika dicampur dalam satu kandang.

Kisah ini berawal ketika As-Samarani baru pulang dari Makkah dan tinggal di Semarang. Dia kedatangan tamu yang terkenal sakti dari Jawa Timur. Saat ditanya As-Samarani, "Anda datang ke sini naik apa?" Sang tamu dengan nada seolah pamer menjawab; "naik harimau". Mendengar jawaban itu AsSamarani kemudian menyuruh santrinya untuk memasukkan harimaunya ke dalam kandang, agar tidak kedinginan atau kehujanan. Sang tamu sempat khawatir dan mencegah perintah As-Samarani kepada santrinya, sebab kambing As-Samarani bisa habis dimakan harimaunya. Keesokan paginya, yang terjadi justru sebaliknya. Sang tamu justru terkejut karena harimaunya yang justru mati tergeletak kaku dalam kandang. Seekor kambing powel yang jenggotnya panjang, mulutnya tampak merah, diduga kuat menjadi pembunuh harimau.

Setelah kejadian ini, pemilik harimau meminta maaf kepada As-Samarani dan menyesali kesombongannya. Sang tamu menyadari bahwa ilmunya tidak sebanding dengan As-Samarani, yang pernah menjadi Qadi di Makkah.

2018, https://www.youtube.com/watch?v=Tseby5lnMiM.

${ }^{42}$ Lihat di lampiran. 
Millatī, Journal of Islamic Studies and Humanities, Vol. 3, No. 1, Juni 2018: 29-50

\section{Kesimpulan}

Ketika melihat literatur-literatur ilmiah, representasi As-Samarani mungkin cukup mudah untuk dicerna karena uraiannya yang sistematis, empiris, dan rasional. Hal ini akan menjadi lain ketika melihat presentasi As-Samarani di dunia maya, terutama dalam hal ini adalah Youtube. Belum bisa dipahami secara utuh apa faktor penyebabnya, ketika video yang populer justru lebih menekankan pada titik tekan kelebihan As-Samarani yang mempunyai kekuatan magis, karamah, atau sesuatu lain yang cukup sulit dijangkau oleh akal. Relasi As-Samarani dengan Kartini, karya Pegon, dua muridnya yang menjadi dua organisasi Islam terbesar di Indonesia, tafsir bahasa Jawa, beberapa hal ini seolah tidak berpengaruh signifikan bagi khalayak umum (baik produser video maupun konsumen) ketika merepresentasikan As-Samarani dalam bentuk video.

Masyarakat awam lebih condong pada sisi magis seperti kemampuan mengubah batu menjadi emas, bertemu imam Ghazali, serta kambingnya mampu mengalahkan harimau. Ada atau tidak keterkaitan dengan upaya untuk memperbanyak penonton dan fee dari Youtube penulis belum sampai pada poin untuk memberikan kesimpulan demikian. Yang jelas, ini sangat menarik, meskipun ada relasinya dengan gema term 'Islam Nusantara ', yang terjadi justru banyak pengangkatan isu magis As-Samarani. Ini sebuah persoalan, karena tidak semua orang mempercayai adanya kekuatan-kekuatan semacam ini.

Bagaimanapun, penting dicatat dan dipahami juga bahwa, apa yang kita sebut magis atau sejenisnya, itu hanyalah asumsi kita sendiri. Kata `magis ` di sini hanyalah asumsi penulis untuk mempermudah pembahasan dan masih bisa diragukan, sebab magis yang kita sebut tidak masuk akal, bagi orang lain justru tidak menutup kemungkinan adalah masuk akal.

\section{Daftar Pustaka}

Al-Zastrouw, Ngatawi. "Mengenal Sepintas Islam Nusantara." Hayula: Indonesian Journal of Multidisciplinary Islamic Studies 1, no. 1 (2017): 1-18.

Ambil Baiknya? RA Kartini Ngaji Sama Kyai Sholeh Darat, Tak Banyak Orang yang Tahu. Diakses 3 Desember 2017. https://www.youtube.com/ watch?v=DTAF3i7Gf_U.

Arifianto, Alexander Raymond. "Islam Nusantara \& Its Critics: The Rise of NU's Young Clerics.” RSIS Commentary, S. Rajaratnam School of International Studies, Nanyang Technological University, 2017. 
—. "Islam Nusantara: NU's Bid to Promote 'Moderate Indonesian Islam.'” RSIS Commentary, S. Rajaratnam School of International Studies, Nanyang Technological University, 2016.

Aziz, Munawar. "Konsep Peradaban Islam Nusantara: Kajian atas Pemikiran Syekh Ahmad Mutamakkin (1645-1740) dan KH Sahal Mahfudz (19372015).” Jurnal Lektur Keagamaan 13, no. 2 (2015): 455-474.

babem ws. Dikunjungi Imam Ghazali | Mbah Sholeh Darat. Diakses 26 Maret 2018. https://www.youtube.com/watch?v=sGPC_SiiDnM.

—. Mau di SOGOK Belanda | KH. Sholeh DARAT. Diakses 26 Maret 2018. https://www.youtube.com/watch?v=KQoN4vXrLpg.

Basid, Abdul. "Islam Nusantara; Sebuah Kajian Post Tradisionalisme dan Neo Modernisme." Tafáqquh: Jurnal Penelitian Dan Kajian Keislaman 5, no. 1 (2017): 1-14.

Basri. "Indonesian Ulama in the Haramayn and the Transmission of Reformist Islam in Indonesia (1800-1900).” Dissertation, University of Arkansas, 2008.

Bizawie, Zainul Milal. Masterpiece Islam Nusantara: Sanad dan Jejaring Ulama-Santri. Tangerang: Pustaka Kompas, 2016.

Burhanudin, Jajat. "Islamic Knowledge, Authority and Political Power: the Ulama in Colonial Indonesia.” Dissertation, Universiteit Leiden, 2007.

Cerita Hari Ini. Kisah Kambing Mbah Sholeh Memakan Macan. Diakses 26 Maret 2018. https://www.youtube.com/watch?v=A2kGHzUWfOU.

Dzahir, Abu Malikus Salih. Sejarah dan Perjuangan Kyai Sholeh Darat Semarang. Disunting oleh M. Ichwan. Semarang: Panitia Haul Kyai Sholeh Darat Semarang, 2012.

Eickelman, Dale F., dan Jon W. Anderson. "Redefining Muslim Publics." Dalam New media in the Muslim World: The Emerging Public Sphere, 2 ed., 1-18. Indiana University Press, 2003.

Faiqoh, Lilik. "Vernakularisasi dalam Tafsir Faid al-Rahman Karya KH. Sholeh Darat al-Samarani." Tesis, Fakultas Ushuluddin dan Pemikiran Islam UIN Sunan Kalijaga, 2017.

Ferry Media Islam. Kisah Nyata Kambing Mbah Sholeh Darat Memakan Macan. Diakses 26 Maret 2018. https://www.youtube.com/ watch?v=u4x7 KPMibcg.

Hall, Stuart. "The Work of Representation.” Dalam Representation: Cultural Representations and Signifying Practices. SAGE, 1997. 
Millatī, Journal of Islamic Studies and Humanities, Vol. 3, No. 1, Juni 2018: 29-50

Hazim, Luqmi Maulana. “Kitāb Al-Mursyid Al-Wajiz fi 'Ilm Al-Qur’ān Al-Ażzz Karya Kiai Șāliḥ Dārāt As-Samārānī.” Tesis, Pascasarjana UIN Sunan Kalijaga, 2015.

Hirschkind, Charles. "Experiments in devotion online: the YouTube khutba." International Journal of Middle East Studies 44, no. 1 (2012): 5-21.

KGS TV Channel. Kisah Murid Mbah Sholeh Darat HD I KH Yahya Al Mutamakkin. Diakses 15 Desember 2017. https://www.youtube.com/ watch?v=GF83szjhhgE.

Klausen, Jytte, Eliane Tschaen Barbieri, Aaron Reichlin-Melnick, dan Aaron Y. Zelin. "The YouTube Jihadists: A social network analysis of AlMuhajiroun's propaganda campaign." Perspectives on Terrorism 6, no. 1 (2012): 36-53.

La Tahzan (Jangan Bersedih). Kisah Kambing Mbah Sholeh Yang Memakan Macan Milik Tamunya Yang Sombong. Diakses 26 Maret 2018. https://www. youtube.com/watch? $v=4$ I-oPoOR8t4.

Luthfi, Khabibi Muhammad. "Islam Nusantara: Relasi Islam dan Budaya Lokal." SHAHIH: Journal of Islamicate Multidisciplinary 1, no. 1 (2016): 1-12.

Masrur, Mohammad. "KYAI SOLEH DARAT, TAFSIR FA'ID AL-RAHMAN DAN RA. KARTINI.” At-Taqaddum: Jurnal Peningkatan Mutu Keilmuan dan Kependidikan Islam 4, no. 1 (2012): 28-45.

Mas'ud, Ali. "Dinamika Sufisme Jawa: Studi tentang Pemikiran Tasawuf KH. Saleh Darat Semarang dalam Kitab Minhaj al-Atqiya'.” Disertasi, Program Pascasarjana UIN Sunan Ampel, 2011.

Media, Kompas Cyber. "Indonesia, Penonton YouTube Terbesar se-Asia Pasifik." KOMPAS.com. Diakses 26 Maret 2018. https://tekno.kompas.com/ $\mathrm{read} / 2015 / 10 / 20 / 17315317 /$ Indonesia.Penonton.YouTube.Terbesar. se-Asia.Pasifik.

mei dhani. KISAH NYATA...!!! KAMBING MBAH SHOLEH MAKAN HARIMAU. Diakses 26 Maret 2018. https://www.youtube.com/ watch?v=PyBal_KpUtw.

Muhamad Aslah. Sejarah Kyai Sholeh Darat Semarang - Sluman Slumun- Semarang TV-Editor Muhamad Aslah. Diakses 10 November 2017. https://www. youtube.com/watch? $=$ JpDuIzWEbhc.

Munip, Abdul. "Tracing the History of the Arabic-Javanese Language Translation Books in Nusantara Islamic Education." Jurnal Pendidikan Islam 5, no. 1 (2016): 43-67. 
Munir, Ghazali. "Pemikiran Kalam Muhammad Salih Darat As-Samarani (18201903).” Disertasi Program, Program Pascasarjana UIN Sunan Kalijaga, 2007.

—. Warisan intelektual Islam Jawa dalam pemikiran kalam Muhammad Shalih asSamarani. Semarang: Walisongo Press, 2008.

Mustofa, Saiful. "Meneguhkan Islam Nusantara Untuk Islam Berkemajuan: Melacak Akar Epistemologis dan Historis Islam (di) Nusantara." Epistemé: Jurnal Pengembangan Ilmu Keislaman 10, no. 2 (2015): 405-434.

Nasihat Kakek. Kisah RA Kartini Jadi Santri Kyai Sholeh Darat. Diakses 3 Desember 2017. https://www.youtube.com/watch? $v=z p L 70 n 0$ QoIQ.

News Semarang TV. Menelusuri Jejak Peradaban Islam di Masjid Sholeh Darat Semarang. Diakses 13 Desember 2017. https://www.youtube.com/ watch?v=D0OnwbZk7go.

Njoto-Feillard, Gwenael. Ripples from the Middle East: The Ideological Battle for the Identity of Islam in Indonesia. Singapore: ISEAS Yusof Ishak Institute, 2015.

Nurkholis, Ahmad. "Karakteristik Tafsir Sufistik Faid al-Rahman fi Tarjamah Tafsir Kalam Malik al-Madyan Karya Muhammad Shaleh Ibn Umar alSamarani.” Tesis, UIN Sunan Kalijaga, 2017.

Official NET News. Soleh Darat, Tokoh Islam Inspiratif di Tanah Jawa - IMS. Diakses 10 Desember 2017. https://www.youtube.com/watch?v=GyqTRvlRBOU.

PAW CHANNEL. Siapa Itu, Mbah Soleh Darat ?, t.t. https://www.youtube.com/ watch? $v=1 \mathrm{AkQOqJGsMA.}$

—. Ternyata! Pendiri NU dan Muhammadiyah Gurunya Jadi Satu. Diakses 30 Desember 2017. https://www.youtube.com/watch?v=nadxx8a4qmk.

Proudfoot, Ian. "A formative period in Malay book publishing." Journal of the Malaysian Branch of the Royal Asiatic Society 59, no. 2 (251 (1986): 101-132.

- Early Malay printed books: A provisional account of materials published in the Singapore-Malaysia area up to 1920, noting holdings in major public collections. Academy of Malay Studies and The Library University of Malaya, 1993.

Qomar, Mujamil. "ISLAM NUSANTARA: Sebuah Alternatif Model Pemikiran, Pemahaman, dan Pengamalan Islam.” El-HARAKAH 17, no. 2 (2015): 198-217.

Roudhoh at-Tholibiin. Kisah Kambing Mbah Sholeh Darat Memakan Macan. Diakses 26 Maret 2018. https://www.youtube.com/watch? v=Tseby5lnMiM.

Saifuddin, Lukman Hakim. "Islam Nusantara dan Pembentukan Karakter 
Millatī, Journal of Islamic Studies and Humanities, Vol. 3, No. 1, Juni 2018: 29-50

Bangsa." Dalam Masterpiece Islam Nusantara: Sanad dan Jejaring UlamaSantri (1830-1945). Tangerang: Pustaka Kompas, 2016.

Samārāni, Muḥammad Șāliḥ bin 'Umar as-. al-Mursyid al-Wajiz fi 'ilm al-Quran al-Aziz. Bombay: al-Matba'ah al-Karimi, 1318.

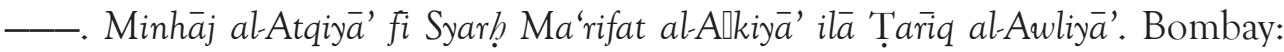
al-Matba'ah al-Karimi, 1317.

Shabir, Muslich. "Corak Pemikiran Tasawuf Kyai Saleh Darat Semarang: Kajian atas Kitab Minhāj Al-Atqiyāa." International Journal Ihya"Ulum al-Din 19, no. 1 (2017): 91-128.

Susarla, Anjana, Jeong-Ha Oh, dan Yong Tan. "Social Networks and the Diffusion of User-Generated Content: Evidence from YouTube." Information Systems Research 23, no. 1 (2012): 23-41.

Tim Penulis JNM. Gerakan Kultural Islam Nusantara. Yogyakarta: Jamaah Nahdliyin Mataram (JNM) \& Panitia Muktamar NU ke-33, 2015.

Umam, Saiful. "Localizing Islamic Orthodoxy in Northern Coastal Java in the Late 19th and Early 20th Centuries: A Study of Pegon Islamic Texts." Dissertation, University of Hawaii at Manoa, 2011.

Yavuz, M. Hakan. "Media Identities for Alevis and Kurds in Turkey." Dalam New Media in the Muslim World: The Emerging Public Sphere, 2 ed., 180-99. Indiana University Press, 2003.

"YouTube." Wikipedia bahasa Indonesia, ensiklopedia bebas, 6 Desember 2017. https://id.wikipedia.org/w/index.php?title=YouTube\&oldid=13420591.

Yusuf Aan. Sirah Kyai Sholeh Darat. Diakses 10 Desember 2017. https://www. youtube.com/watch? $=$ YDfgtfB8n8o. 